\title{
PENYULUHAN MANAJEMEN PETERNAKAN ITIK SISTEM INSTENSIF DI DESA BAGIK NYAKA SANTRI
}

\section{EDUCATION OF INTENSIF DUCK POULTRY MANAGEMENT IN BAGIK NYAKA SANTRI VILLAGE}

\author{
Mohammad Hasil Tamzil, Budi Indarsih \\ Laboratorium Produksi Ternak Unggas Fakultas Peternakan Universitas Mataram, \\ Jalan Majapahit, Nomor 62, Kota Mataram, Provinsi NTB, 83115 \\ ${ }^{*}$ Alamat korespondensi: emhatamsil@yahoo.com
}

(Tanggal Submission: 12 Maret 2020, Tanggal Accepted: 30 April 2020)

\begin{abstract}
ABSTRAK
Kegiatan penyuluhan bertujuan untuk memberikan tambahan pengetahuan kepada peternak itik di desa Bagik Nyaka Santri, kecamatan Aikmel, kabupaten Lombok Timur dalam mengatasi berbagai problema dalam budidaya ternak itik secara terkurung. Kegiatan penyuluhan terselenggara berkat kerjasama antara Kelompok Peternak Itik Tunas Sederhana Bagik Nyaka Santri dengan staf pengajar pada Laboratorium Ternak Unggas, Fakultas Peternakan Universitas Mataram. Penyuluhan dilaksanakan dengan metode ceramah dan diskusi. Materi penyuluhan meliputi: pembibitan, pakan dan pemberian pakan, sistem pemeliharaan, penyakit dan pencegahan penyakit, serta pengelolaan pasca panen. Semua rangkaian acara berjalan lancar serta semua peserta penyuluhan mengikuti rangkaian acara dan tanya jawab dengan serius. Materi penyuluhan dipandang sebagai materi yang sangat dibutuhkan oleh peserta. Dengan demikian dapat disimpulkan bahwa materi penyuluhan yang diberikan dapat menambah wawasan peserta untuk mengatasi persoalan-persoalan yang muncul dalam beternak itik secara terkurung.
\end{abstract}

Kata kunci: penyuluhan, peternakan itik, sistem intensif

\section{PENDAHULUAN}

Ternak itik merupakan ternak ungas yang mempunyai kontribusi cukup besar sebagai penghasil telur konsumsi. Produksi telur konsumsi Nasional pada tahun 2018 mencapai angka $2.228,33$ ton, dari jumlah tersebut sebanyak $7,36 \%$ (302,70 ton) berasal dari telur itik (Kementan, 2018). Produksi telur itik tersebut sebagian besar berasal dari peternakan kecil yang menyebar di pelosok pedesaan yang dipelihara secara ekstensif, yaitu dipelihara secara gembala dan mengandalkan areal penggembalaan sebagai sumber pakan. Pemeliharaan secara intensif dihadapkan dengan kendala tingginya harga pakan komersial, sehingga pengembangan itik petelur dalam skala besar sukit diterapkan.

Seiring dengan perkembangan zaman, beternak itik dengan sistem ektensif sulit untuk dipertahankan. Hal ini disebabkan karena pengaruh keterbatasan lahan penggembalaan dan tingginya pencemaran lingkungan karena penggunaan pestisida oleh petani untuk membasmi hama dan penyakit, maka pemeliharaan secara intensif merupakan solusi sebagai sarana penyedia telur itik.

Dalam upaya meminimalis biaya pakan dalam pemeliharaan ternak itik secara terkurung, maka penggunaan pakan komersial yang memiliki harga tinggi harus dikurangi dan menggantinya menggunakan bahan pakan alternatif yang 
tersedia. Bahan-bahan pakan alternatif yang mempunyai nilai gizi tinggi dan sudah terbukti berpengaruh positif terhadap kinerja produksi telur harus diperkenalkan melalui berbagai media kepada masyarakat pengguna, sehingga biaya produksi per butir telur itik dapat ditekan. Hal inilah yang melatarbelakangi kegiatan yang berjudul "Penyuluhan Menejemen Beternak Itik Secara Instensif Di Desa Bagik Nyaka Santri untuk Meningkatkan Kemampuan Peternak dalam Mengelola Usaha" dilakukan.

\section{METODE KEGIATAN}

\section{Mitra Pelaksana}

Kegiatan penyuluhan terselenggara atas kerjasama dari berbagai pihak, antara lain: Kelompok Peternak Tunas Sederhana Bagik Nyake, Aparat Desa Bagik Nyaka Santri, kecamatan Aikmel, Lombok Timur, dan Staf Pengajar Laboratorium Ternak Unggas, Fakultas Peternakan Universitas Mataram.

\section{Peserta}

Peserta aktif dari kegiatan penyuluhan ini terdiri dari beberapa komponen, yaitu Petani Peternak (peternak itik) termasuk peternak pemula, wakil Kelompok Wanita Tani, wakil Assosiasi Wanita, serta wakil Assosiasi Wisata Lombok Timur. Dalam kegiatan tersebut hadir pula kepala Pusat Kesehatan Hewan Lombok Timur, ketua kelompok kampong unggas, Pendamping Program Peternakan Lombok Timur, serta utusan Dinas Peternakan dan Kesehatan Hewan Lombok Timur.

\section{Mekanisme Persiapan Acara}

Terselenggaranya kegiatan pengabdian ini didasarkan atas permintaan ketua Kelompok Peternak Itik Tunas Sederhana ke Laboratorium Ternak Unggas Fakultas Peternakan Universitas Mataram. Pada tahap selanjutnya ketua Kelompok Peternak Tunas Sederhana mengundang berbagai komponen (kelompok) masyarakat, diantaranya adalah: Kelompok Peternak (peternak pemula dan peternak sukses), Kelompok Wanita Tani, Assosiasi Wanita, dan Assosiasi Wisata Lombok Timur.

\section{Tempat dan Waktu}

Kegiatan penyuluhan ini dilaksanakan pada hari Kamis, tanggal 12 April 2018, mulai dari jam
9.00 Waktu Indonesia Bagian Tengah sampai selesai, bertempat di Aula Kantor Desa Bagik Nyaka Santri, Aikmel Lombok Timur.

\section{Metode Pelaksanaan}

Metode yang dipergunakan dalam kegiatan penyuluhan ini adalah metode ceramah, diskusi dan tanya jawab.

\section{HASIL DAN PEMBAHASAN}

Acara penyuluhan dilaksanakan di Aula Desa Bagik Nyaka Santri, kecamatan Aikmel Lombok Timur. Acara berlangsung selama 4 jam, dengan susunan acara terdiri dari kata-kata pengantar oleh ketua Kelompok Peternak Tunas Sederhana, kata-kata sambutan oleh Kepala Desa Bagik Nyaka Santri, dan dilanjutkan dengan acara penyuluhan. Materi penyuluhan mencakup semua aspek beternak itik yang diberikan secara umum. Materi-materi tersebut adalah: 1) Pembibitan ternak itik yang mencakup pemilihan induk, pemilihan telur tetas, penetasan menggunakan mesin tetas serta metode seksing dan grading anak itik umur sehari. 2) Pakan dan pemberian pakan ternak itik semua fase umur (starter, grower, dan layer). 3) Sistem pemeliharaan ternak itik termasuk system perkandangan dari fase starter sampai layer. 4) Bioskuriti dan pengenalan penyakit itik. 5) Penanganan pasca panen, termasuk teknologi pengolahan seperti pembuatan telur asin dan telur asap. Materi penyuluhan disampaikan dengan metode ceramah, tanya jawab, dan tukar pengalaman. Gambar 1a memperlihatkan salah seorang anggota tim pelaksana sedang menyampaikan materi ke peserta penyuluhan.

Acara penyuluhan berjalan lancar sesuai dengan rencana. Penyampaian materi penyuluhan diikuti dengan seksama oleh semua peserta. Semua peserta mengikuti materi secara serius (Gambar 1b). Tingkat keseriusan peserta dapat dilihat dari antusiasnya dalam acara disikusi dengan meyampaiakan semua persoalan dan masalah yang dihadapi dalam proses budidaya. Persoalan-persoalan yang dihadapi peserta masih berkisar pada masalah budidaya dan pengolahan pasca panen. Pada aspek pakan muncul persoalan tingginya harga pakan komersial dan rendahnya produksi telur. Rendahnya produksi telur disebabkan oleh faktor internal dan eksternal. Faktor internal adalah factor dari individu ternak 
(faktor genetic) dan umur ternak itik yang tidak seragam. Faktor eksternal adalah factor yang mendukung keberlangsung hidup ternak itik untuk dapat berproduksi dengan baik. Hal-hal yang masuk dalam kategori factor eksternal antara lain adalah kualitas dan kuantitas pakan, system perkandangan, serta menejemen pemeliharaan.

Ternak itik yang dipelihara peternak mempunyai mutu genetik yang sangat beragam. Ternak dengan kemampuan produksi telur tinggi bercampur dan dipelihara bersama dengan ternak itik dengan tingkat kemampuan produksi telur rendah (Hardjosworo, 1990). Dampaknya adalah biaya produksi tidak sebanding dengan produksi telur, sehingga terkesan usaha beternak itik petelur tidak menguntungkan. Persoalan tingginya keragaman produksi telur itik ini diperparah oleh tingkah laku penyedia itik dara yang sering mencampur itik dengan berbagai tingkat umur untuk mencukupi jumlah pemesanan (Tamzil, 2017). Persolan ini merupakan persoalan yang mendesak untuk diselesaikan. Program seleksi secara terencana dan terprogram harus dilaksanakan, sehingga bibit yang dikeluarkan breeder adalah bibit unggul dengan kualitas tinggi.

Itik dengan mutu genetik tinggi akan memperlihatkan performa bertelur yang baik bila disertai dengan system pemeliharaan yang baik pula (Tamzil, 2017). Produksi telur itik yang dipelihara dengan digembalakan hanya mencapai $26,9-41,3 \%$, sedangkan bila dipelihara secara intensif produksi telur dapat mencapai angka $55,6 \%$ (Setioko, 1990), bahkan dapat mencapai angka $69,4 \%$ selama 1 tahun (Ketaren dan Prasetyo, 2000; Ketaren, 2002).

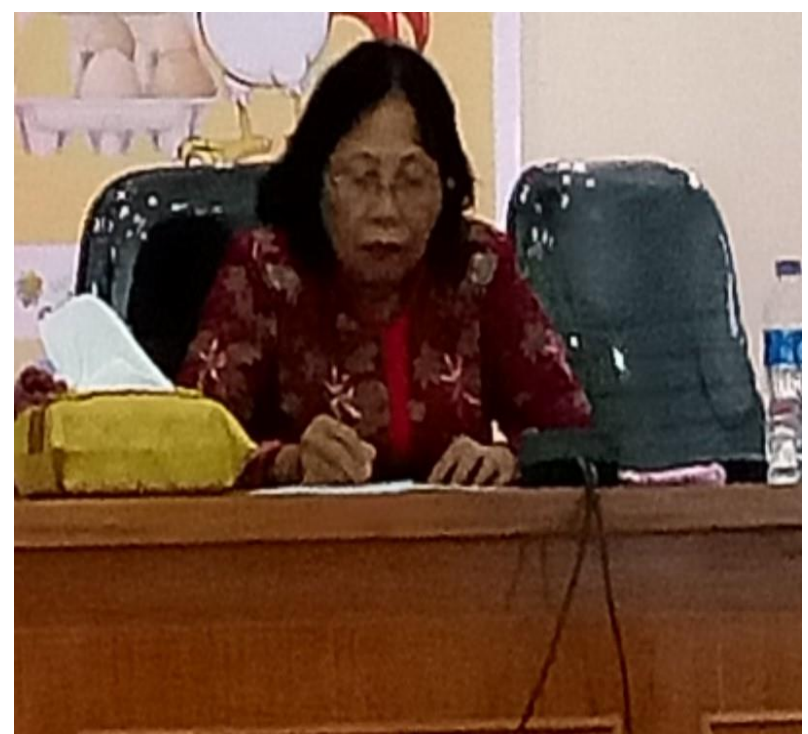

Gambar 1. Pemberian Materi Oleh Penyuluh

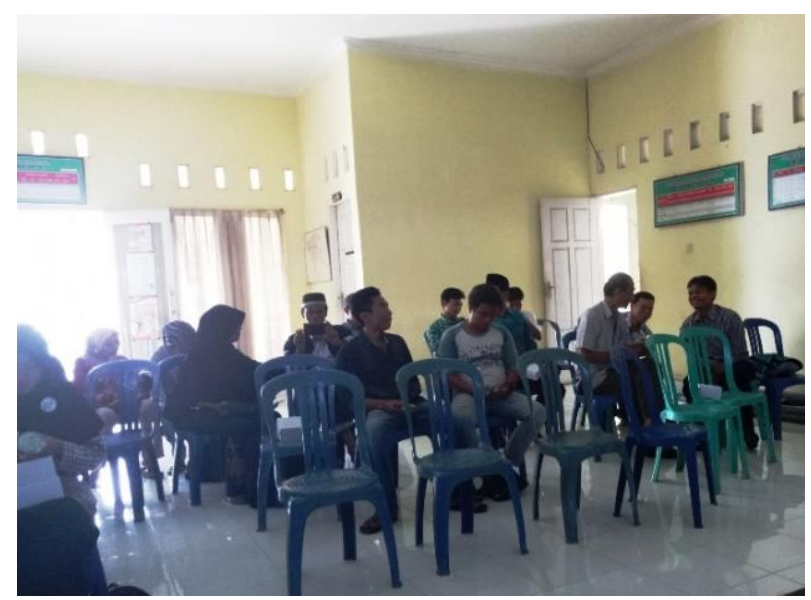

Gambar 2. Peserta Kegiatan Penyuluhan

Dalam upaya mengurangi tingginya biaya pakan, peternak disarankan menggunakan bahan pakan lokal. Di daerah perkotaan banyak tersedia limbah makanan dari Rumah Sakit atau dari Restoran. Di daerah sentra indusdtri pengalengan ikan dan udang tersedia limbah yang dapat dimanfaatkan sebagai bahan pakan. Daerah lokasi penyuluhan dan sekitarnya tergolong daerah pertanian subur beririgasi teknis dengan pengadaan air irigasi tersedia sepanjang tahun. Pada daerah dengan profil seperti ini tersedia biota-biota yang sangat baik untuk bahan pakan itik. Di daerah persawahan, selokan, dan daerah berair lainnnya merupakan area yang banyak dihuni keong mas dan duckweed. Kedua biota perairan ini sangat baik untuk bahan pakan itik (Tamzil, 2017). Keong mas merupakan sumber protein dan betacarotin untuk ternak itik. Penggunaan keong mas sebagai bahan pakan itik 
menghasilkan produksi telur yang cukup tinggi dan dengan kulaitas kuning telur yang sangat baik (Tamzil, 2017). Demikian pula halnya dengan Duckweed, tumbuhan aquatic ini sangat disukai oleh ternak itik baik dalam bentuk segar maupun dalam bentuk kering (Indarsih dan Tamzil, 2012).

Persoalan lain yang muncul dalam diskusi adalah pengelolaan pasca panen, yaitu sistem pembuatan telur asin panggang. Karena singkatnya waktu yang tersedia, persoalan ini tidak dapat dibahas tuntas. Penyuluh berjanji untuk menyajikan masalah tersebut di lain waktu dan kesempatan, yang sampai saat ini masih belum bisa terealisasi. Perlu diprogramkan sehingga semua persoalan yang muncul mendapat solusi jalan keluar.

Beberapa faktor pendukung yang mempercepat pencapaian tujuan penyuluhan ini antara adalah: 1). Inisiator terselenggaranya acara penyuluhan ini adalah ketua Kelompok Peternak Itik Tunas Sederhana. Kelompok Peternak itik ini sudah berusia puluhan tahun dengan jumlah anggota dan pemilikan ternak itik yang makin bertambah. Anggota kelompok menyebar pada berbagai desa di berbagai kecamatan di kabupaten Lombok Timur. 2). Peserta pelatihan sudah banyak yang menggeluti pekerjaan beternak itik dalam kurun waktu yang cukup lama dan masuk sebagai anggota Kelompok Beternak Itik Tunas Sederhana. 3). Materi yang disampaikan sangat sesuai dengan kebutuhan. 4). Umur peserta rata-rata umur produktif, yaitu umur yang cenderung rasa ingin tau dan keberanian berspekulasi cukup tinggi. Beberapa factor yang dianggap sebagai kelemahan adalah: pelaksanaan penyuluhan bersifat insidental; penyampaian materi hanya ceramah (tidak dibarengi dengan praktek); serta tidak ada tindak lanjut pembinaan. Faktor-faktor in diprediksi tidak memberi pengaruh optimal pada penyelesaian persoalan yang dihadapi peternak. Oleh sebab itu dalam upaya memperbesar makna penyuluhan yang telah dilakukan, ke depan perlu ada tindak lanjut kegiatan, sehingga semua persoalan yang dihadapi peternak mendapatkan solusi, termasuk teknik membuat telur asin panggag dapat dikuasai peternak.

\section{KESIMPULAN DAN SARAN}

Kegiatan penyuluhan di desa Bagik Nyaka Santri, Aikmel, Lombok Timur yang dilaksanakan oleh staf pengajar Laboratorium Ternak Ungags Fakultas Peternakan Universitas Mataram bekerja sama dengan Kelompok Peternak Itik Tunas Sejati berlangsung lancar sesuai dengan tujuan dan target sasaran. Agar supaya pesan-pesan yang telah disampaikan saat penyuluhan berlangsung dapat diaplikasikan dengan baik, disarankan untuk dilakukan pembinaan lanjut melalui pelaksanaan penyuluhan ualang atau dengan mendifinitifkan desa lokasi sebagai desa binaan Universitas Mataram.

\section{DAFTAR PUSTAKA}

Kementan. 2018. Statistik Peternakan dan Kesehatan Hewan. Dirjen Peternakan dan Kesehatan Hewan, Kementrian Pertanian Republik Indonesia. Jakarta.

Hardjosworo, P.S. 1990. Usaha-usaha peningkatan manfaat itik Tegal untuk produksi telur. Dalam: Prosiding Temu Tugas Sub Sektor Peternakan, Pengembangan Ternak Itik Di Jawa Tengah. 6-9.

Indarsih, B and Tamzil M.H.. 2012. Feeding Diet Containing Different Form of Duckweed on Productive Performance and Egg Quality of Ducks. Media Peternakan. 35(2):128-132.

Ketaren, P.P. dan Prasetyo L.H.. 2000. Produktivitas Itik Silang MA Di Ciawi dan Cirebon. Prosiding Seminar Nasional Peternakan dan Veteriner. Pusat Penelitian Peternakan, Badan Penelitian dan Pengembangan Pertanian, Departemen Pertanian.

Ketaren P.P. 2002. Kebutuhan Gizi Itik Petelur dan Itik Pedaging. Wartazoa Vol. 12 No. 2: 3746.

Setioko A.R., Sinurat, A.P. Setiadi, P, Lasmini A., Ketaren P, dan Tanuwidjaja A. 1992. Pengaruh Perbaikan Nutrisi Terhadap Produktivitas Itik Gembala pada Masa Boro. Prosiding Agroindustri Peternakan Di Pedesaan. Balai Penelitian Ternak, Ciawi, Bogor.

Tamzil, M.H. 2017. Ilmu dan Teknologi Pengelolaan Plasma Nutfah Ternak Itik. Penerbit Mataram University Press. Mataram. 